\title{
Wartime Film Stardom and Global Leadership
}

\author{
Charlie Chaplin and Mary Pickford led Pershing's Crusaders and America's \\ Answer into the enemy's territory and smashed another Hindenburg line. \\ GEORGE CREEL, $1920^{1}$
}

\section{PREPAREDNESS, WAR, AND CONSUMERISM}

In the first chapter I discussed how U.S. government agencies set into motion a range of propaganda initiatives that relied on an unprecedentedly close collaboration with Hollywood. In this chapter I focus on the same wartime relationship from the standpoint of the film industry. Specifically, I am interested in exploring Hollywood's response to the heightened patriotic climate of the war years-before and during America's actual intervention-not in terms of individual films but in terms of the industry's pursuit of national significance. The war granted a novel political authority to some of Hollywood's greatest celebrities, particularly Mary Pickford and Douglas Fairbanks, turning them from icons of lowbrow amusements into recognized representatives of American patriotism. This dynamic occurred just as Hollywood sought to gain economic and cultural legitimacy through financial consolidation and international expansion. To support the war effort, the industry had to make sensitive decisions in terms of pleasing both patrons and exhibitors. If films with overtly patriotic themes helped advance the argument that filmgoing was not an irresponsible wartime amusement, they still needed to walk a fine line between patriotism and entertainment value. Taking her cue from an expression of the time, Leslie Midkiff DeBauche describes such a combination as "practical patriotism.".

In the years prior to America's entry into the First World War, the protection of the country was central to the debates surrounding so-called war preparedness. Men and women were featured in numerous films fighting to protect their home soil, including Sigmund Lubin's The Nation's Peril (1915), J. Stuart Blackton's Battle Cry

of Peace (1915), and the Public Service Film Company's Defense or Tribute? (1916). Narratives and mode of address were not indifferent to gender. Elizabeth Clarke 
has showed that when the narrative action was about domestic defense, heroic women appeared regularly as daring defenders of the home or the nation. ${ }^{3}$ The serials Pearl of the Army (1916) and Patria (1917), for instance, introduced the very possibility of foreign invasion but cast strong and independent heroines as the first line of defense. Played by star actresses Pearl White and Irene Castle respectively, these serialized adventure tales turned the political issue of preparedness into entertaining narratives aimed at the industry's largest segment-interclass and multiethnic female audiences. Released in conjunction with print versions in the Sunday papers, these serials popularized their elegant queens as fashionable models of vigorous Americanness, thereby contributing to a commodification of patriotism. As White's and Castle's politicization fully capitalized on their gendered identity, consumerism was inscribed in the logic of war necessity and thus not at odds with patriotic obligations to frugality and sacrifice. ${ }^{4}$ Once the war began and narratives started focusing on military expansion and not defense, violent actions appeared as a "man's game."' Female heroine figure did not disappear, Clarke argues, but their stunning on-screen accomplishments were narrowed to a more polarizingly gendered necessity: military recruitment. Even in films released before the declaration of war, including Womanhood, the Glory of the Nation (April 1917), the promotional discourse shifted from celebrating the image of its star, Alice Joyce, to campaigns for male enlistment-despite the film's title. ${ }^{6}$ But Alice Joyce was no Pickford.?

In her systematic assessment of Hollywood's film production during America's actual war engagement between April 1917 and December 1918, DeBauche has argued that "in proportion to the number of films [released], the number of films bearing any relation to the events of the war was small," amounting to 14 percent of a total of 568 titles. Half of those were newsreels or documentaries. Mainstream film producers did not exploit the war themes of preparedness or even full engagement and began releasing war-related films in larger numbers only around "September 1918, two months before the signing of the Armistice." The limited number of war-related productions, however, did not imply that they were insignificant in terms of trade or public discourse. War-related films constituted half the industry's output of prestigious "specials," longer and more expensive productions, released between April 1917 and December 1918. Furthermore, the entire film industry, including producers, exhibitors, reviewers, stars, and spectators, were debating "the appropriate function of popular culture, especially during a period of national crisis." Hollywood's response to the declaration of war was remarkable not just for what it did for the patriotic cause, but also for what it enabled the film industry to achieve culturally and commercially in the short and long terms.

In DeBauche's analysis, Hollywood's practical patriotism took two main narrative directions: an antagonist one, featuring ruthless German enemies, and a celebratory one, stressing American heroes' resistance and ultimate victory. Among the productions falling into the first category were "hate the Hun" propaganda 
films, which included The Kaiser, the Beast of Berlin (1918) and Raoul Walsh's The Prussian Cur (1918). Of the films in the second group, the most famous were Cecil B. DeMille's The Little American (1917), shot just days after the United States declared war and starring Mary Pickford, and D. W. Griffith's Hearts of the World (May 1918), starring Lillian Gish. Set in France, the latter repurposed the moralistic message of Intolerance (1916) with the urgent agenda of American patriotism, but its dated Manichean melodrama turned Griffith "from being the father of the cinema to being its grandfather." ${ }^{10}$ His quintessential leading lady, Gish, seemed to be an outmoded "picture personality" that Pickford, with her multidimensional and extracinematic fame, was fast replacing.

\section{LITTLE 100-PERCENT WHITE AMERICAN}

By the time Pickford made The Little American, she had already become a paragon of film popularity and publicity. During the first days of block booking, Pickford's steady production of six or eight features a year, compared with Chaplin's two-reel shorts, had made her a distribution force for whatever company with which she was working. ${ }^{11}$ More than any other star, she was uniquely capable of driving "the marketing of movie fan magazines, postcards, posters, trading cards, buttons, and photographs." ${ }^{12}$ A savvy businesswoman, she managed her fame through control of her print visibility. Between late 1915 and late 1916, she signed a syndicated newspaper column, "Daily Talks," ghostwritten by her close friend and scenarist, Frances Marion. ${ }^{13}$ The column offered "helpful beauty secrets, advice on friendships, and memories of her 'happy girlhood,' " and answered her readers' questions. ${ }^{14}$ In one June 1916 column, Pickford/Marion enthusiastically praised the Citizens' Preparedness Parade that had taken place a month earlier in New York City. It was a daring move since, as Wilson was campaigning for reelection on an isolationist platform, military preparedness did not yet constitute a mainstream position. Still, the procession represented a call to arms because it awakened a patriotic spirit that Pickford's later involvement with the war bond drives would fully unleash. ${ }^{15}$

Of the eight films that Pickford released during America's involvement in the war, halfway into her career as Hollywood superstar, only The Little American (July 1917) and Johanna Enlists (September 1918) dealt with the conflict. The former was a blockbuster; the latter wasn't. Production for The Little American, under the direction of Cecil B. DeMille, began a week after the war declaration, on the same day the CPI was established, on April 13, 1917. Shooting continued during the national mobilization and was released on July 2, 1917, as the nation was preparing its armies to go overseas. Back in March, a month before production had started, Jesse L. Lasky had told DeMille that he wanted the film to arouse "the spirit of preparedness [. . . ] in American girlhood and womanhood." Lasky wrote to DeMille that he intended to create a character that "typifies the spirit of the American Girl in War times, something that would portray a girl in the sort of 
role that the feminists in the country are now interested in-the kind of girl that dominates $[, \ldots]$ who jumps in and does a man's work when men are at the front." ${ }^{\prime 6}$ Pickford's persona on and off screen conveyed an iron-willed patriotism without running the risk of destabilizing gender roles. The Little American inaugurated such charming and unthreatening political commitment in a way that ultimately shaped her later screen characterizations.

In the film, Pickford plays the role of Angela Moore, a young and naïve American woman from Washington, DC. Her first name and her birthday (July 4) make her a symbol of goodwill and American innocence. Angela is in love with Karl Von Austreim, a German American living in the United States. When the war breaks out, Karl is asked to return to his native land and join the fight as a German officer. Shortly afterward, Angela sails for Europe to assist her dying French aunt, and she survives a torpedo attack before finally reaching her destination. Her aunt has died, but Angela decides to stay and aid wounded French soldiers. When the German forces occupy and pillage the village, she becomes their prisoner and is almost raped by a drunken Karl, who stops himself only after recognizing her. After Angela persuades him to switch sides out of his love for her, he helps her smuggle information to the French army. Eventually caught, they are brought before a firing squad but are liberated by a timely bomb blast. One of the film's key dynamics is Angela's transformation from victim to a patriot who is unwilling to stand idle in the face of German atrocities. The intertitles that express her reaction eloquently capture and repeat Wilson's public stance with a timely and perfect rhetorical pitch:

I was neutral-'till I saw your soldiers destroying women and shooting old men! Then I stopped being "neutral" and became a human being! [...]

I am done with you and your Emperor! I'd rather die free than live in the grip of your damnable "system."

While her character's change of opinion is critical to the film's plot, it also encapsulates the different ideological positions of the time-from idealistic pacifism to practical preparedness to staunch military support. The Little American was one the most successful films of the entire war period, and Pickford's dramatic patriotic performance "cast the shadow of the war on all her films." ${ }^{17}$ For instance, in June 1917 the Duluth News-Tribune hailed the film as an extension of her "moral, mental, and physical support of the flag." ${ }^{18}$ Under the spell of the conflict, Vachel Lindsay later mused that "to repudiate this girl in haste is high treason to the national heart," since "democracy crowns those it loves." ${ }^{19}$ It should not be surprising then that The Little American's release coincided with the first circulation of Pickford's promotional tag lines "America's Sweetheart" and "Our Mary." ${ }^{20}$ What is certain that the film served the Toronto-born Pickford as a springboard for her new patriotic reputation.

From the spring of 1917 and throughout 1918, the press extensively praised Pickford's support for the war effort: fundraising, giving speeches at benefits, and 


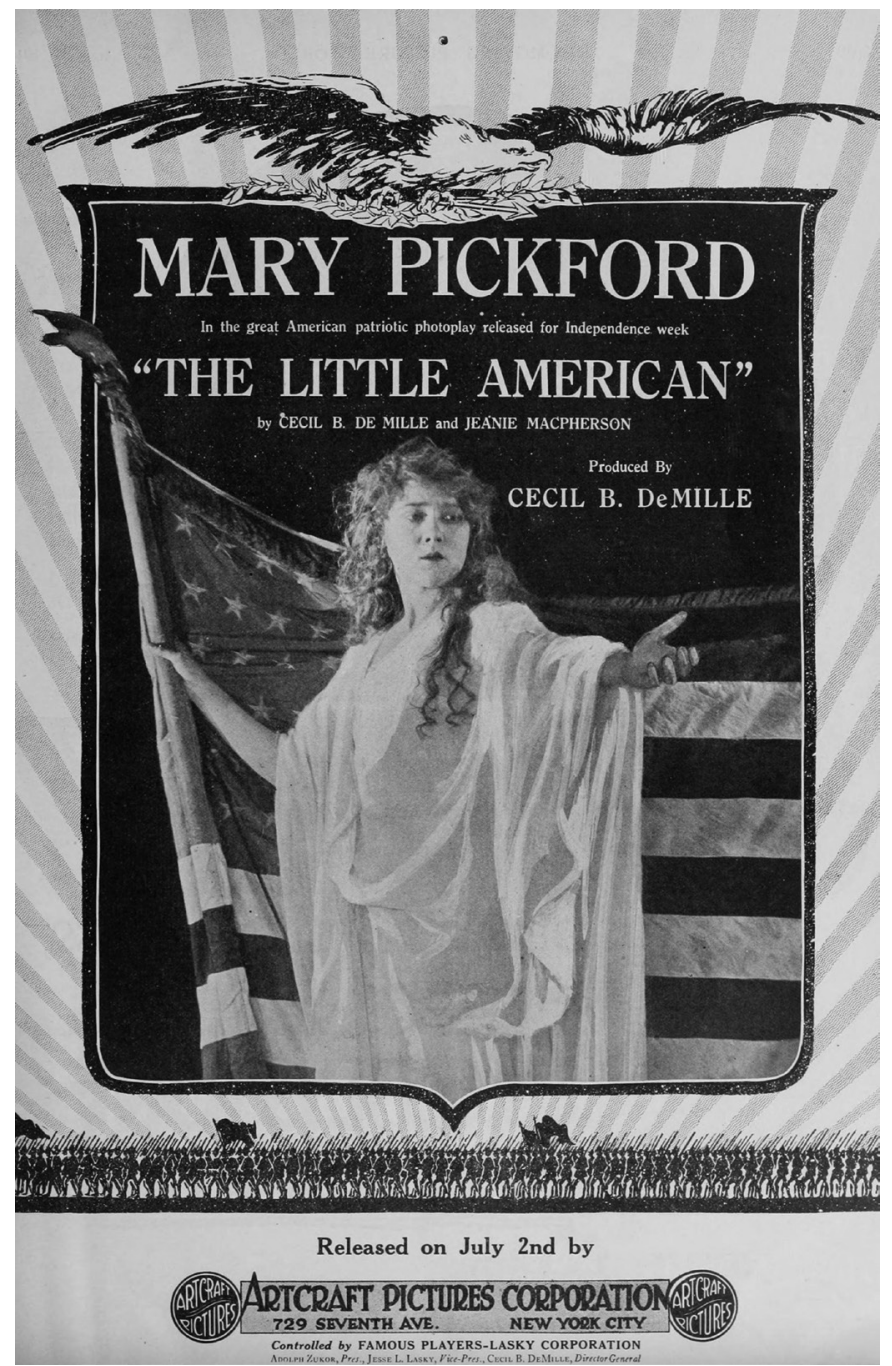

FIgURe 6. Advertisement for The Little American (Mary Pickford Co., 1917). Motion Picture News, June 23, 1917, 3833.

releasing the short, lighthearted comedy 100\% American (1918) to publicize war bonds. The most visible result of all this activity was the Third and Fourth Liberty Loan campaigns, held in both Washington, DC, and New York City in the spring of 1918 and featuring Pickford, Fairbanks, and Charlie Chaplin, among others. ${ }^{21}$ After the New York drive, the stars brought the campaign to the rest of America along with their films: Pickford covered the West Coast, Fairbanks the Midwest, and Chaplin the South. ${ }^{22}$ 
The press described Pickford as a "modern Joan of Arc" and stressed that the actress had done more for the cause than "soldier, king, pot or prophet." ${ }^{23}$ Throughout the latter part of 1917 and into 1918, Pickford enhanced her cinematic persona to the level of national cultural icon and opinion leader. Her growth as a public figure did not mean abandoning her long-standing association with roles of very young women characters. Almost exactly bookending The Little American were two productions that cast Pickford as an eleven-year-old girl: The Poor Little Rich Girl (March 1917) and Rebecca of Sunnybrook Farm (September 1917). ${ }^{24}$ Nonetheless, something else had changed since 1916.

Until that year, Pickford had played many characters of non-European descent. These included a Native American in Ramona (Biograph, 1910) and A Pueblo Legend (1912), a Mexican in Two Brothers (1910), and a Filipina in A Manly Man (1911). Pickford played the majority of her nonwhite roles from 1909 to 1912 and, after a short hiatus, resumed playing them in 1915 , by interpreting a Native Alaskan woman in Little Pal and a Japanese one in Madame Butterfly.25 Yet, a year later, as Elizabeth Binggeli has shown, "these nonwhite characters abruptly disappeared from her repertoire." ${ }^{26}$ After 1916, looking like Pickford meant looking indisputably white. This was not the case for other popular stars, including Norma Talmadge and Colleen Moore, who continued to be exoticized with dark makeup. ${ }^{27}$ While it is true that Pickford's film impersonations in this period included frequent roles as little girls and even as unattractive women, as in Stella Maris (January 1918), these changes revealed her growth more in acting virtuosity than in racial adaptability. She could cast aside her maturity, her femininity, or her charisma, but "after 1916, Pickford did not cast aside her whiteness." Whiteness came at a dramaturgic cost. While in general an idealized white masculinity meant a "noble mastery over base bodily desires, including lust, greed, and violence," the idealized white femininity rested on the embodiment of virtue. ${ }^{28}$ Yet, the mere display of virtue itself posed a challenge to narrative developments since generally it is desire, and not virtue, that provides dramatic intensity. The solution for Pickford's characters was to situate their whiteness in a preadolescent youth.

Critics and biographers have often discussed Mary Pickford's career in terms of the resilience of her roles as a child or a young girl against the frequency of more mature ones. In contrast to her amazingly savvy "creative authority over her silent film career," as Gaylyn Studlar has rightly noted, "many of her most important and popular films present her in the role of a child." ${ }^{29}$ Still, if we look at her career in the context of the nation's preparation for and experience of the war, something else becomes clear. Out of the fifty-two feature films in which Pickford acted, she plays a little girl in only seven of them, and in only three does she remain a child throughout the story. Significantly, these three films are from 1917, the first year of America's war involvement: The Poor Little Rich Girl, Little Princess, and Rebecca of Sunnybrook Farm. Further, her post-1917 collaboration with the former combat correspondent Frances Marion, whose contribution to Pickford films at least 
from The Poor Little Rich Girl on was particularly evident in the pungent humor of the intertitles, helped consolidate Pickford's association with the playful and vital stubbornness of her young characters.

By relying on "juvenescence, virginity, righteousness, feistiness" and embodying a "hyperbolic white femininity," Pickford could embrace a virtuous and resourceful screen persona capable of "tragedy with innate feistiness." ${ }^{\circ}$ Rather than facing immutable bodily and social limits, her character could achieve final victory through "her indomitable white spirit." ${ }^{11}$ It was the victory of a young white person's free spirit that overcame either the narrative stasis associated with traditional female roles or the doom linked to an apparently insurmountable inferior identity. ${ }^{32} \mathrm{Her}$ screen persona, in other words, embodied the combative and energized possibility of growth and self-improvement rather than that of resignation and invariable destiny. The comedy effects of some of her films derive from the relief, as Binggeli has noted, "that her backwardness is merely a product of acculturation and dirt, not a problem of blood." 33

By largely impersonating white characters and by being Anglo-Saxon herself, Pickford had it both ways: she could effortlessly display racial privilege while aligning herself with the early-twentieth-century framework of "personality," which identifies an individual not on the basis of an inner core or unchanging character, as was typical in the nineteenth-century epistemology of personhood, but from acts of self-improvement and performance. ${ }^{34}$ During the war years, in other words, Pickford's film characterization coherently intertwined youth and whiteness into a celebrity who, beyond her innocent impersonations and wholesome acting style, exuded racialized patriotism and success from every pore.

Her prewar and wartime screen presence and her visibility on magazine covers, in product advertisements, and on postcards had stressed a coherent image of a down-to-earth everywoman, sporting long, dangling, golden locks but also capable of saucy banter and heroism. On screen and off, Pickford projected ideas of indomitable courage and moral righteousness into her films' domestic and foreign markets. After having stopped playing nonwhite roles and after years of impersonating white working-class or immigrant figures, her American charm became synonymous with white people's resilience and resourcefulness. Her characters' actions amounted to a "hunt for happiness and beauty in the face of misery and ugliness," which embodied two prewar American attitudes: "the 'practical idealism' of Herbert Spencer's Social Darwinism, and the advocacy of social change of Lester Frank Ward's Reform Darwinism." 35

In the 1920s Pickford's political import and recognizable style, made of classically simple tastes in fashion and couture, turned out to be somewhat at odds with the growing popularity and appeal of transnational actors of less immaculate whiteness. To best frame our understanding of this shift, I shall first address the war's impact on the stardom of the other all-American superstar of the time, Pickford's soon-to-be husband, Douglas Fairbanks. Secondly, I shall discuss the 
postwar reorganization of the industry in terms of financial consolidation and cultural institutionalization that increasingly led Hollywood to appreciate its public relations clout abroad as well as domestically.

\section{FAIRBANKS, DEMOCRATIC AND ELITIST}

Publicity at any price has become the predominant passion of the American people.

ANita loos, opening title, His PICTURES IN THE PAPERS (1916)

A star of the New York stage, in the spring of 1915 Douglas Fairbanks transitioned from light stage comedies to light film comedies that revealed an appealing "masculinity that danced a national optimism through speed, agility, and aggressiveness." ${ }^{36}$ In late 1916, George Creel, soon to head the CPI, wrote his admiration of Fairbanks's "dynamic individuality," ${ }_{73}$ and a few months later Photoplay foresaw his career as "not only a triumph of acting but a national expression." 38 Starting with his film debut and throughout the second half of the teens, Fairbanks's Americanness emerged in spirited, resourceful, and optimistic characterizations that turned gangster and Western narratives as well as comic melodramas into social satires and energy-filled sermons. His comic adventures addressed widespread anxieties about office life, corporate hierarchy, and careerism and their combined threat to virile American manhood. His films often combined a romantic narrative with a free-spirited display of masculine instincts juxtaposed to the danger of overcivilization, usually represented by a corporate office job. As Michael Kimmel and others have shown, the regeneration of American masculinity was inherently contrary to the pervasiveness of corporate desk jobs with their modern sites (i.e., office buildings), technologies of interaction (i.e., typewriters and memos), and social encounters, particularly between individuals of different gender and national backgrounds. ${ }^{39}$ In a modern workplace that had finally allowed women, though mainly as typists and stenographers, exclusively white male homosociality was a thing of the past. Fairbanks's leading roles provided two recurring types of masculine self-affirmation and adaptation to these new environments, neither of which were particularly open to interactions with novel types of female characters.

One quality unifying his films is the light, satirical tone of his characters' actions and viewpoints. As Alistair Cooke remarked back in 1940, titles like His Picture in the Papers (February 1916), Reaching for the Moon (November 1917), and A Modern Musketeer (December 1917) "parodied, with no discernable time-lag, the pattern of a rapidly changing social scene." ${ }^{40}$ With a very American and at times very populist taste that Fairbanks himself helped fashion, his characters "briskly demolished" several affectations of his day, including "the Eastern clubman, pacifists, blue-bloods, ouija boards, slumming parties, pictorial journalism, nervous breakdowns, bobbed hair, and Couéism." ${ }^{41}$ This playful and humorous 
disapproval confirmed Fairbanks as the same jovial star underneath the clothes of whichever character he was playing. Mostly set in present-day America, his satirical films were also self-reflexive regarding the nature of Hollywood fame. At the end of His Picture in the Paper, after Fairbanks's character has secured enough press coverage to prove his manhood and marry his beloved, the final winking intertitle, "Ain't he the REEL hero?", teasingly associates the story's narrative arc with the made-up nature of film celebrity. In his volume on Fairbanks, Richard Schickel has aptly argued that the post-World War I novelty of celebrity status pertained to "the realms of play" rather than to the traditional notion of worthy achievement. ${ }^{42}$

Still, satire did not exhaust his characters' approach to the issue of masculinity in a corporatized world. Fairbanks's more practiced solution was the revitalizing adventure set in the West or in faraway lands. This had already been apparent in The Lamb, his first film. As the weakling son of a wealthy New York family, his character undergoes a transformation through time spent in the wilderness. Given the fame of Theodore Roosevelt as the most prototypical masculine hero of such transformative narratives, Fairbanks's audiences could appreciate both the "farcical excesses" of his performances and the familiar "stereotype of the westernized Easterner." 43 "In this West," Studlar has noted, "even a mollycoddle could attain a manhood in which natural primitive urges found expression because such experience recapitulated the past." 44 While these transformations were generally interlaced with a good dose of comedic and athletic antics, in times of war the regenerative power of the "wilderness cult" maintained a vigorous cogency. ${ }^{45}$

Most of his screen roles did not explicitly address the European conflict or America's subsequent involvement. Still, Fairbanks's public contribution to the Liberty Bonds campaigns, through public appearances and promotional films, allowed his persona to become an all-American icon. ${ }^{46}$ In a remarkable photograph from one of his public appeals, taken on April 8, 1918, Fairbanks is seen campaigning for the Third Liberty Drive at the Sub-Treasury Building in New York City, now the Federal Hall National Memorial, transfixing a large crowd beneath American flags and sharing the platform with an imposing statue of George Washington (figure 7).

Despite his intense visibility at these rallies, his only film to address war mobilization explicitly was the antipacifist In Again-Out Again (April 30, 1917), released three weeks after the U.S. declaration of war against Germany and following months of division between promoters of preparedness and pacifism. In the film Fairbanks is Teddy Rutherford, a properly named advocate of preparedness, engaged to a dull and pale girl named Pacifica Jennings-named after the former antiwar secretary of state, William Jennings Bryan. In addition to scenes meant to deride peacemakers, the display of Teddy's athletic energy and vigorous handshake aligns the film's ideological stance with one of the war's most familiar proponents. Written by Anita Loos and directed by her husband, John Emerson, the film was 


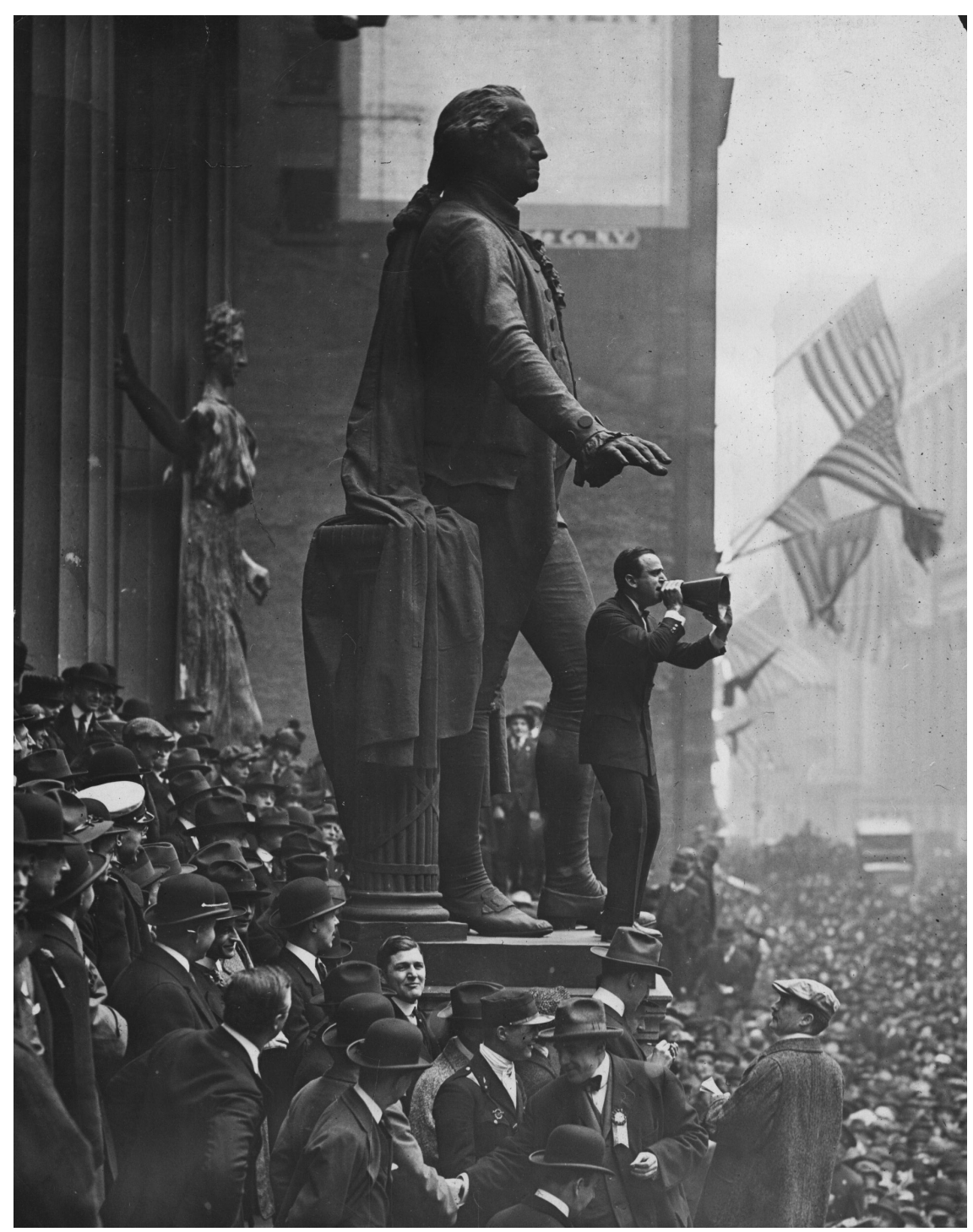

FIGURE 7. Douglas Fairbanks speaking about Liberty Loans in front of the Subtreasury building. Photograph from the Douglas Fairbanks Collection, General Publicity, Academy of Motion Pictures Arts and Sciences. Courtesy of AMPAS.

the first one to be released by Artcraft Pictures Corporation, a distributor for Paramount. Artcraft marketed it by flooding newspapers with "full-page ads stating that Uncle Sam congratulated Fairbanks on 'his great patriotic picture $[, \ldots]$ the most timely feature in months, teeming with action, patriotism, thrills 
and laughs." "47 The film and its campaign burnished Fairbanks with a novel patina of patriotic pride. Other Rooseveltian references would soon follow in his works.

A few Fairbanks films from 1917 juxtaposed country and urban lifestyles by making explicit references to the personality of his lifelong idol, President Roosevelt, and his known fondness for the strenuous life. In the comedy-Western Wild and Woolly (June 1917), Fairbanks played the son of an eastern railroad tycoon, sophisticated and fond of dime novels but unaccustomed to life on the frontier. Once he is sent to the West to investigate the feasibility of a new railroad route, he proves himself to be a pugnacious leader and is rewarded with success and romantic love. The same Rooseveltian contrast between corrupting city life and regenerative country life was also at the center of The Down to Earth (August 1917), which a critic dubbed as "a five-reel Fairbanksian sermon for Teddy Roosevelt." ${ }^{48}$

Along with Roosevelt, another of Fairbanks's heroes and a close friend, at least for a while, was the religious preacher Billy Sunday, a "baseball evangelist" who shared his athleticism, goodwill, and sense of tough-minded brotherhood.49 Between 1908 and 1918, roughly corresponding to the emergence of Fairbanks's career, Sunday delivered his popular sermons in week-long road shows, filled with tricks, speeches, and athletic entertainments. ${ }^{50}$ In 1918, Fairbanks and this "gymnast for Jesus," as Sunday was often dubbed, appeared in baseball uniforms at a benefit to raise funds for American soldiers in France. To many the two figures seem to have congenially similar personalities. The friendship did not last. Although Americanism had a positive ring for domestic audiences, it could easily turn into aggressive nationalism. When Sunday's post-1918 sermons favored the extermination of the German race, Fairbanks was nowhere to be seen.

Fairbanks's religious vocation, which consisted of preaching the optimistic sermon of physical fitness against social ills, pretensions, and fears, made him akin to what Cooke described as a "popular philosopher." ${ }^{51}$ This was not just an effect of the films on which a loyal group of collaborators routinely worked-from the aforementioned Loos and Emerson to writer-directors Allan Dwan and Joseph Henabery. It was part of the Fairbanks brand, which promoted character building through physical fitness and was broadcast in interviews, fan magazine columns, and biographical profiles, as well as several ghostwritten volumes, including the bestselling Laugh and Live (1917) and Making Life Worthwhile (1918).52 "He was a muscular itinerant preacher," Cooke pointedly observed, "sailing gaily into the social novelties and the occupational neuroses of a new era dizzy with growing pains." 53

During the war years, a new facet in Fairbanks's screen characterizations began to appear, though it would fully develop only in the 1920s: an elitist tendency suffused his persona in a few films made between 1917 and 1919. Fairbanks's characters were increasingly transformed from outsiders, who were quick to deride 
the rituals and pretensions of Old World nobility, to American aristocrats. Joining the familiar routines of social mockery and derision was a novel endorsement of personal ambition and entitled leadership. As an explicitly American outcome, such celebration solved the apparent contradiction between social and national predestination and individual merit.

America has always had its elites. In the preindustrial period, elites marked their difference from the nouveaux riches through an emphasis on ancestry, education, and taste. Any individual achievement had to be balanced and filtered by membership in clubs, Blue Books, and private schools. A few Fairbanks films from this period foreground these tensions between aristocracy and merit-based individualism. In American Aristocracy (November 1916), he plays Cassius, a preindustrial "natural" aristocrat and scion of one of America's first families. Although he is named after the Roman senator who conspired with Brutus to kill Caesar, this historical figure's repute in contemporary America was that of honorable patriot, capable of killing a dictator for the creation of a republic. ${ }^{54}$ Cassius-Fairbanks operates in a world that looks down on "upstarts," "climbers," and trade in general. While Cassius is virile and daring, his romantic rival is a fearful malted-milk manufacturer. Cassius invents a new hatpin that makes him rich: in combination with his prestigious lineage, such an outcome represents the perfect American amalgam of earned success and aristocratic predestination. This conjunction of a sense of special distinction with the notion of American exceptionalism recurs in The Americano (January 1917), Reaching for the Moon (November 1917), and His Majesty the American (August 1919) - all set in imaginary republics and kingdoms. ${ }^{55}$ In these films Fairbanks is no longer the gymnastic evangelist but a new American aristocrat who sports the Hamiltonian mantle of autocratic leadership and who, due to his inherent superiority, is able to bring democracy to Europe and Latin America. ${ }^{56}$ Fairbanks's works, even in their comedic tempo, exuded a Rooseveltian temperament that bestowed upon his protagonists a cogent ethic of personal and global leadership. ${ }^{57}$ For instance, His Majesty the American, released a few months after the signing of the Treaty of Versailles in June 1919, provides an example of "imperial reach" that powerfully appropriates Old World traditions and Americanizes them by sheer force. ${ }^{58}$ The costume adventures of the 1920s, set in distant times and exotic locations, showcase a more aggressive American aristocratic character without losing the familiar ironic touch. From The Mark of Zorro (1920) and Robin Hood (1922) to The Iron Mask (1929), Fairbanks would often become the champion of the oppressed in distant countries or centuries-a neat conjoining of Rooseveltian masculinity with Wilsonian idealism.

Pickford's and Fairbanks's respective wartime cultivation of an all-American identity would expand after the war. The two stars took part in the post-Armistice Fifth Liberty Bond drive (April 1919), known as the Victory Loan, during which they continued to publicize their good relationship with 
the president (figure 4). They also continued to position themselves as dignitaries at home and in the international scene. Before returning to discuss their postwar careers, we need to examine the financial and commercial infrastructural context that made postwar American cinema dominant domestically and internationally and enabled this couple to remain a paragon of all-Americanness in 1920 s film and public culture.

\section{HOLLYWOOD POWER AND PERSUASION}

The war provided a jolt to the challenges that the film industry had been facing since well before the U.S. military went to Europe. These included films' standardized length, commercial incorporation and financing, studios' publicity hype vis-à-vis promotion of screen personalities, and threat of censorship vis-à-vis the industry's aspiration to cultural relevance. The war helped to reframe such challenges by repositioning American cinema nationally and internationally. For instance, the recasting of the geopolitical and financial relationships between the United States and European countries significantly affected Hollywood's commercial reach, institutional role, and ideological import. Stars turned out to be privileged vectors for film companies' balance sheets and domestic market shares, as well as for Hollywood's emerging public profile as a main driver of national and international public opinion.

The drive toward cultural institutionalization and financial incorporation had started even before the studios were set up in Hollywood. By the mid-1910s, producers had begun to adapt to the new feature-length format and reduce the number of pictures. The trend escalated during the war. Although the conflict and the Spanish influenza diminished foreign distribution, the overall decrease in the number of titles and reels was also part of a deliberate "fewer and better" strategy.59 Out with the cheaper pictures, in with "specials," which, while often associated with stars, secured higher rental costs, longer runs, and higher admission prices. Even independent productions featured celebrities as several stars sought to acquire independence from mainstream studios, avoid paying income war tax, and produce works of higher artistic merit.

During the war, Famous Players-Lasky and the First National Exchange Circuit began acting like integrated corporations that competed over stars' salaries and credits. The company led by Adolph Zukor was originally a studio that entered the distribution business after it acquired Paramount. First National followed the opposite path: from distribution to production. Established three weeks after the U.S. declaration of war, it brought together independently owned theaters and state rights franchisees to consolidate exhibitors' interests against Paramount's controlling distribution practices. Most prominent among such practices was block booking, wherein the major studios forced exhibitors to rent packages of minor films in order to secure stars' pictures. First National's strategy was to corner 
the exhibition business by creating alliances among the country's most prominent movie theaters and forcing scores of small, independent, and rural movie houses out of business. In a system of flat rental fees, theater chains had gained much clout over distributors. Competition between Zukor and First National raised the need for outside financing to acquire, control, or build movie theaters and produce films featuring ever more expensive stars: "the single most important factor determining a film's box office success." ${ }^{\prime 0}$ Pickford and other screen icons found themselves in the middle of this war and sought to benefit from the practice of star-series distribution. ${ }^{61}$ Between 1917 and 1918, First National began to hire away Zukor's precious commodities: Pickford, Chaplin, and Lillian Gish, as well as Constance and Norma Talmadge. Zukor's response provided the second act of his ongoing battle with First National.

After 1919, emboldened by a fresh infusion of stock financing, Zukor began building and acquiring controlling interest in numerous first-class movie theaters (more than three hundred theaters by mid-1921), which had been First National's initial key asset. ${ }^{62}$ In response, through mergers and Wall Street financing, First National entered directly into the field of production by building its first studios in California. Meanwhile, taking advantage of the ongoing duel between Zukor and First National, film exhibitor Marcus Loew created MGM in 1924 by merging Metro Pictures Corporation with Goldwyn Pictures Corporation. ${ }^{63}$ By the mid-1920s, a few vertically integrated corporations came to dominate the industry through their control of theaters and the employment of a variety of "monopolistic trade practices such as block booking, blind bidding, price fixing, and a system of unfair clearances and runs." ${ }^{64}$ If these could be seen as the unredeemable features of a shady business, the regularity of profits, the secure financial return of stars' contracts, and the acquisition of prime real estate (or "fixed assets in the balance sheet" in accountants' parlance) reassured Wall Street that the film industry was a solid business.

Financing film production, directly or through securities, had already been attempted before the war, but after Triangle Film Corporation's 1917 financial debacle, the industry underwent a number of structural changes, particularly in terms of partnerships among exhibition outlets or between production and distribution firms. ${ }^{65}$ Broader conditions had also changed. Film stardom had grown into a giant national and international cultural phenomenon; Hollywood exercised a novel hegemony in international distribution; and Wall Street firms had amassed tremendous liquidity in conjunction with massive credit extended to European banks and companies. This last point deserves closer examination in light of its larger geopolitical implications.

Even during America's neutrality, the war had offered new commercial and financial opportunities to American companies that maintained relations with all belligerents in the conflict. According to historian Mary Nolan, "U.S. exports increased from $\$ 2$ billion in 1913 to $\$ 6$ billion in 1916," and several banks, 
most prominently J. P. Morgan and Company, were the beneficiaries of these international transactions. ${ }^{66}$ To pay for these war goods, Britain sold its foreign investments, sent gold to America, and borrowed billions from U.S. banks. The consequences of Europe's massive dependency on the United States were significant: the Old World lost its prominence in the world's financial and commercial traffic, America "moved from being a debtor nation to being the world's number one creditor," and "New York replaced London as the center of world finance." ${ }^{67}$ It was a momentous change in the "character of transatlantic and global capitalism and consumer culture." ${ }^{68}$ A new global geofinancial nexus would also soon shape Hollywood and American film culture.

To conduct its foreign policy, the U.S. government began to engage private financial interests in projects of unprecedented scale and reach. Wall Street firms started conducting financial rehabilitation of foreign countries in the service of the U.S. national interest. While masking the projects as civilizing missions, these firms became "financial missionaries to the world." ${ }^{9}$ The internationalization of the American film business was part and parcel of a geoeconomic policy that aimed to secure the political stability of countries identified as important to U.S. governmental and business elites. War propaganda made it easy to appreciate that a successful policy of American economic intervention would turn foreign countries into investment sites and markets for American goods and lifestyles. ${ }^{70}$ The Wilson administration had been active on this front early on. The Webb-Pomerene Act of 1918 granted immunity from antitrust regulation to companies that, once organized into exporting cartels, operated in a trade deemed to be essential to the war effort.

Geopolitical strategies brought structural changes to the home front. With the strengthening of the U.S. commercial and financial sectors, as Wasko has noted, "more money became available for industries that were proven according to the investment community's standards." By the end of the war, the film business had begun to meet those requirements by developing basic industrial methods and establishing both a national distribution system and an international one that extended to the Far East and South America. ${ }^{71}$ Quite importantly, as the film industry began to oversee its international reach from New York City and no longer from its London offices, it came to center both global film distribution and finance in the United States. ${ }^{72}$

Beginning in 1919, a new era of movie financing began. Studios turned to investment banks to raise funds by selling stocks and bonds or turned to commercial banks to secure loans. A February 1920 article in Variety, while inaccurately prophesying the imminent involvement of J. P. Morgan, described the unprecedented incursion of Wall Street's financing power into Hollywood's commercial sovereignty as an "invasion." 73 While there is no evidence that J. P. Morgan considered entering the film business before the 1930s, other bankers did, including Otto and Felix Kahn of the investment bank Kuhn, Loeb and 
Company and Amadeo Peter "A. P." Giannini and his brother Attilio Henry Giannini of Bank of America. ${ }^{74}$ After establishing itself as a rival to J. P. Morgan through considerable financial involvement in the railway business, during the war Kuhn, Loeb and Company managed to establish a credit relationship with France and with the city of Paris. In 1919, flush with financial resources, the firm underwrote a \$10 million stock issue to Zukor's Lasky Corporation/Paramount, the most important film company in America and thus in the world.

Kuhn, Loeb and Company's financial decision was based on domestic and international considerations. Before proceeding, the company had commissioned H. D. H Connick, vice president of the Morgan-controlled financial firm American International Corporation, to do a complete study of Famous PlayersLasky. ${ }^{75}$ Filled with statistics and financial data related to imported and exported films, box office receipts, and numbers of foreign movie theaters, the study concluded that the largest returns were in exhibition, not production. Addressing the widespread concern that stars' salaries were a major industry problem, the report described compensation as a matter of supply and demand and identified performers as the key to a film's exhibition and financial prospects. ${ }^{76}$ The report praised Famous Players-Lasky's stars and directors, who gave tangible value to the company's films, but also suggested, in an overt recognition of the role of publicity, "a more aggressive sales campaign" to increase domestic and foreign rental returns. ${ }^{77}$

Though the report was undated, its emphasis on publicity coincided with the publication of a special section on film publicity in the July 1918 issue of Moving Picture World..$^{7}$ The section ran thirty-five pages and included a snapshot history of publicity and short articles "by the leading motion picture publicity men," some thirty department heads and press agents. One of the contributors, James L. Hoff, defined publicity in opposition to advertising. While advertising consisted of "display announcements written by an ad writer," Hoff argued, publicity consisted of "text matter that is written by a press agent." The key difference pertained to cost: "the display is paid for and the publicity is not."79 For many other contributors, the value of free publicity depended on press agents' ability to tailor a message to a specific newspaper's needs. "The newspapers want short stuff, snappy and to the point, and so written that it does not have to be rewritten," maintained one of them. ${ }^{80}$ Publicity could effectively migrate from a studio's press office or the desk of a star's agent onto a newspaper page if it could masquerade itself as news and secure the widest possible attention as such.

Possibly more openly than any other banker, Otto Kahn showed great appreciation for the ways the film business could mold public opinion through news publicity. In an address entitled "The Motion Picture," delivered at the Paramount sales convention banquet on May 2, 1928, in Washington, DC, he spoke as an industry advocate. He intertwined praise for motion pictures' soundness as both a business and a vector of public sentiment with the recognition of their 
American, democratic, and even idealistic value. ${ }^{81}$ To explain how motion pictures took hold of "the emotional impulses of the people" and represented the most effective democratic factor in American life, even ahead of the automobile and the radio, he told of a curious historical coincidence. He recounted the public response to the deaths of former Harvard University president Charles William Eliot and, of all people, Rudolph Valentino, which in his account occurred on the same day, August 23, 1926. ${ }^{82}$ Both deaths made news, but the reactions of the American media and people were dramatically different. For the Harvard president, Kahn remarked, "public opinion rendered respectful and reverential tribute." ${ }^{83}$ News of Valentino's death, in contrast, "brought forth a veritable flood of popular grief, expressing itself in almost hysterical demonstrations as his body was transported across the country." As a response to those who had denounced the disparity of merits and reactions, not to mention the questionable taste of public demonstrations, Kahn pointed out what today might seem obvious: cinema's unique capacity to arouse mass responses.

Rather than being a cheap or morbid fad, Kahn continued, for many millions, Valentino represented "the very embodiment and symbol [of] romance, beauty, grace, chivalry, and youth" because "his art and personality on the screen had endowed, enriched, and beautified their lives." ${ }^{84}$ News of his death revealed motion pictures' triumph as a most appealing modern phenomenon worthy of most serious cultural consideration-and thus beyond the fact that "the credit facilities [...] are ample [and] their securities have a ready market." Kahn invited his audience of investors and businessmen not to linger on high-minded objections but to appreciate the distinctively American features of motion pictures' popularity and to consider the commercial and geopolitical advantages of American cinema's world success. ${ }^{85}$ As both art and popular entertainment, Kahn posited, motion pictures "present a striking parallel to that dualism of the spiritual and material which I consider as one of the most notable and distinguishing characteristics of America." For Kahn, cinema constituted that most American combination "in fifty-fifty proportion" of "hard-headed business capacity and deep-seated idealism" that could secure major geopolitical returns. ${ }^{86}$ As a wartime practitioner of coupling financial returns with propaganda, Kahn was a most credible postwar advocate of aligning Hollywood's international commercial success with American cultural influence. His speech ultimately sought to persuade his listeners to divorce cinema from mere entertainment and appreciate it instead as "an advertising medium of remarkable effectiveness in making known all kinds of American products throughout the world" and thus in shaping world's public opinion about the United States. ${ }^{87}$ Kahn's reference to film stars as Hollywood's prime commodity showcases his understanding of their role as the nation's ambassadors in advertising testimonials. It is now time to turn to this dimension of the motion picture business - that is, the enormous role of international film distribution and its key publicity vehicle: the stars. 


\section{GLOBAL REACH}

American film manufacturers need a world-trade, not merely a local fetchand-carry.

PHOTOPLAY, $1921^{88}$

One of the most important dynamics affecting postwar American cinema was Hollywood's growing worldwide hegemony. The war favored U.S. companies in the competitive European markets by, for instance, cutting off France from Central and East European markets and the Germans from the Allied film circuits. ${ }^{89}$ According to a 1930 Harvard Business Review article, by 1925 American films made up to 95 percent of the total shown in Great Britain, 70 percent in France, 65 percent in Italy, and 60 percent in Germany. "Few American industries," the business periodical concluded, "are more dependent on foreign markets than the motion picture industry." ${ }^{\circ}$ By the late 1920s, foreign markets amounted to about 35 percent of Hollywood's total income..$^{91}$ Together with Wall Street financing, the income from foreign distribution helped studios seek control or ownership of the best domestic theaters, raise their films' production values, and compete for and develop top global stars. In turn, these additional commercial and entertainment advantages helped sustain Hollywood's success abroad.

This outcome resulted from several concomitant factors but also stemmed from a sustained collaboration between Hollywood and the U.S. government that went back to the First World War. The American film industry received key logistical and publicity help from the CPI during the war. By virtue of the U.S. government's control of the wireless, cable, and postal services across the Atlantic, the CPI was able to place said services at the disposal of the film industry, particularly through the Foreign Film Division. All told, "some 24 nations were sent 6,200 reels of American pictures." ${ }_{92}$ In return, the CPI received the authority from the War Trade Board to issue licenses to Hollywood films destined for the world's markets, which Creel used to distribute CPI works. The same licensing clause applied to foreign exhibitors, who, if found exhibiting German films, were prohibited from receiving Hollywood fare. Distribution of the latest Signal Corps and American commercial films to Allied populations brought together the government and the film industry's respective goals: war propaganda and commercial profitability. ${ }^{93}$ To paraphrase Creel's famous sentence, Chaplin and Pickford led Pershing's Crusaders and America's Answer across territories where they would have otherwise remained unseen and unwanted. ${ }^{94}$

While Creel's intention was to exercise a good measure of control over foreign film markets, the resulting CPI policies achieved unexpected long-term results. As the U.S. government broadcast American values and lifestyles through printed and visual media, Hollywood stars nurtured habits, expectations, and the international appetite for even more American culture. "The advertising that America obtained [. . .] by the CPI," Larson and Mock recognized, "played no small part 
in the great commercial expansion enjoyed in the 1920s."95 The industry took advantage of this partnership. In the summer of 1917, the National Association of the Motion Picture Industry (NAMPI) "was elected to membership in the U.S. Chamber of Commerce," which signaled its "recognition within the wider business and financial community." ${ }^{96}$ In 1918, during negotiations over foreign film distribution, Hollywood obtained recognition of its distinct patriotic and educational role, which extended not just to "news weeklies, screen magazines, [and] American travelogues" but also, as a NAMPI-CPI agreement reads, to "films purely entertaining in nature, but which clearly portray some idea of American life and purpose."97

The combined effects of the weakening European film industry and American cinema's growing hegemony over Europe mainly through block booking and direct control of major movie theaters were long lasting. The trade expressions of the time, "Film America" (for Hollywood) and "Film Europe" (for a pan-European film industry devoted to Continental coproductions), informed a wave of press coverage that characterized their relationship as nothing short of an "undeclared war." "In a ridiculously short time span," wrote a German trade paper in 1926, "Film Europe has become a colony of Film America."98

The conventional view about the 1922 establishment of the Motion Picture Producers and Distributors of America (MPPDA), replacing NAMPI, is that the latter found itself to be ineffectual in protecting the film industry's public stance from the many scandals that had tarnished it in the late 1910s and early 1920s. ${ }^{99}$ Wall Street investments had to continue and the alliance with the government had to be reinforced against the censorship calls made by religious and moral constituencies. While historically valid, this argument tends to overlook that the MPPDA's newly appointed head, Will H. Hays (formerly Republican National Committee chairman, manager of Warren G. Harding's successful presidential campaign, and U.S. postmaster general), had two main goals: to ward off censorship legislation and to enhance Hollywood's international domination. The order of priorities might even be reversed. "The MPPDA's original bylaws," notes Kristin Thompson, "charged it to represent the industry's interest abroad." MPPDA ultimately operated as a public relations machine that changed Hollywood's actual import, not just its image, in the country and the world.

To quash calls for federal censorship, Hays stressed an approach that relied on industrial organization and an idealization of "self-government." ${ }^{101}$ To represent the film industry's international interests, Hays relied on a Wilsonian rhetoric of universalism that was clearly accented with notions of exceptionalism. $\mathrm{He}$ promoted cinema as enhancing "the international understanding by the peoples of the world" but maintained that only "America in the very literal sense is truly the world state. All races, all creeds, all men are to be found here."102 But he also publicized and practiced the Wilsonian principle that "western ideas go in with the western goods" and the selling of American goods will "convert the people of the world to the principles of America." ${ }^{103}$ In a 1923 speech delivered in London, 
Hays outlined the international aims of the film industry: "we are going to sell America to the world with American motion pictures." 104 "Trade follows the films" became a trope in film and business periodicals. ${ }^{105}$

While embedding his defense of the film business into a universalistic and suggestive rhetoric of republican ideals of democracy and self-determination, it is not surprising that Hays viewed the MPPDA "almost as adjunct of our State Department." ${ }^{106}$ After developing a strong collaboration with the U.S. Department of Commerce, whose Bureau of Foreign and Domestic Commerce offered key assistance in gathering information on foreign markets and critical advice for negotiating foreign countries' protectionist policies, Hays fostered an even closer alliance with the State Department. ${ }^{107} \mathrm{He}$ understood that an alliance with the government departments responsible for negotiating with foreign governments would be instrumental in expanding the film industry's global presence. While the United States may not have had a clearly defined domestic or a foreign film policy, Hays did. In his view, Hollywood facilitated America's global economic and political preeminence within a new global cultural perspective. By the same token, the recognition of America's place in the world impacted the nation's self-understanding and appreciation of what cinema could be as powerful global vernacular.

At a time when, in Victoria De Grazia's words, "hard-bound lines [. . .] still divided the high and academic from popular and mass cultures" in Europe, American cinema's popularity made Europeans question "whether old-world states still exercised sovereignty over their citizens' leisure." ${ }^{108}$ Was American culture so powerful and pervasive because of the country's decisive role in winning the war, superior industrial and commercial organization, and ensuing economic occupation of foreign film industries? Or was it because it uniquely appealed to European audiences of all classes through its dynamically acted and appealingly shot stories of optimism, resilience, and final justice? In other words, was Hollywood success the result of power or persuasion? De Grazia notes that European commentators touched upon both explanations but, she maintains, "arguably, American movies were more responsive to consumer desires than European films," particularly in conveying new, attractive "social identities" that exuded glamour and individual achievement. ${ }^{109}$ Although they had emerged out of a distinctively multinational Pacific Coast outpost and displayed a sort of "Norman Rockwell preciousness," these figures-Hollywood stars, that is-appeared to Europeans unmistakably American. ${ }^{110}$

To spectators at large, no matter their national, class, or ethnic background, Hollywood stars appeared as models of individual distinction, enviable lifestyles, and universal desires. To the studios, stars represented loyal brands, vectors of high and standardized quality, sold to both exhibitors and audiences and publicized to the point of saturation in tabloids, film periodicals, and even the daily press. If the war had helped to sell America, the celebrities of the 1920 s were doing the heavy lifting at a time when the advertising industry was relying on their mass appeal to design its pitch and reach. Referring to a 1917 Vogue article entitled 
"Great Actors, as Other Great Men, Are More Alive Than the Herd," Jackson Lears notes that the great actor was exploited as cheerleader, "rousing inert masses into disciplined enthusiasm." As "redemptive celebrity figures" and "demigods on the field," Hollywood stars "became standard features in the testimonial advertising that blossomed after the war." 11

What was there to sell? The narrative and stylistic appeal of American cinema relied on the aestheticization of an ideological cosmos at once American and universal, animated by such values as freedom, youth, optimism, and leadership. ${ }^{112}$ During the war and immediately after, Pickford and Fairbanks were two of the most authoritative-and marketable-representatives of this etiological universe whose aura reverberated far outside movie theaters. As democratic leaders of public opinion, at least for a few years, they did not seem to have many rivals. And yet, in the 1920s, their all-too-American allure left a wide-open space for different kinds of marketable characterizations.

\section{PICKFAIR'S OLD DIGNITARIES}

Beginning in the early 1920s, despite her continuous success, Mary Pickford's much-praised image of innocence and virtue became increasingly at odds with the new national mood and with her own real age. "America's Sweetheart" sought to move away from her traditional roles as young girl, but the results were mixed. In the ten reels of Little Lord Fauntleroy (1921), she gave an unprecedentedly bravura performance as both a boy and his mother, but her role as Spanish street singer in Ernst Lubitsch's Rosita (1923) was too much of a radical departure from her public image. Her 1920 marriage to her boy-man did not mean the end of her conventional childish roles, made of curls and long skirts. But the conservative image was a paradox for her career. While the aestheticized nostalgia she continued to exude in film after film, from Through the Back Door (1921) to Sparrows (1926), was particularly successful in small-town America, it condemned her to being an anachronism.

Opposing her curls was the bobbed hair of the flapper, who became synonymous with the modern, worldly woman, who was American in youth and sexual daring but cosmopolitan in manners and fashion. Between 1919 and 1920 Alla Nazimova, Constance Talmadge, and Gloria Swanson adopted the new hairstyle just as the passage of the Nineteenth Amendment had begun to have a special significance for younger generations of fans who viewed new grooming and dress codes as evidence of expected emancipation. Unlike Pickford's characters, real and fictional flappers were young women comfortable with their overt sensuality, as Clara Bow, Louise Brooks, and Joan Crawford were to reveal. By the middle of the decade, gossip columnists were publishing career obituaries about Mary Pickford. Her "reign is over," the former unofficial Valentino publicist Herbert Howe noted in 1925: "she has outlived the popularity of her type." In her place, he 
wrote, "We now have with us the flapper generation that rolls both its socks and its cigs, and even hips a flask now and then." ${ }^{113}$ The flapper's worldliness did not just signify her loss of innocence and a bold assertion of sensuality; it also signaled a cosmopolitan that reproduced the "infinitively more attractive [. . .] sophistication of old Europe."114 After describing the flapper as "the most authoritative and intelligent movie reviewer," Howe elected her as the true "representative public" vector of the new Hollywood taste, since "it doesn't matter much what men like; the women lead to the box office." ${ }^{115}$

Throughout the 1920s, the domestic authority Pickford had gained as a cultural icon during the war kept declining. America was elsewhere, and Pickford, now in her late thirties, had overextended her youth. When Pickford had her hair bobbed after her mother's death in June 1928, the event made the front page of the New York Times. ${ }^{116}$ Grief, rage, and disappointment were some of the sentiments expressed by her nostalgic fans. Even though her first talking picture, Coquette (1929), became her biggest box-office success and secured her an Academy Award for Best Actress, the career of "the Bank of America's sweetheart," as Zukor once called her, was ending. ${ }^{117}$ Her popularity remained strong abroad, where her enduring American appeal was always connected to the figure of her dashing, energetic, but also aging husband.

In the 1920s, Fairbanks's popularity and characterizations were changing too. In longer and ever more expensive productions, set in past fictional worlds without flapper-like female coprotagonists, his roles became less and less about social satire. Instead they promoted a proud, often juvenile display of all-American male leadership-even if the character was not American. Regularly set in a familiar literary past, his 1920 s films cast him as a hero-leader whose ironic take on distant settings and cultures showed him off as morally and physically superior. In truth, his characters did not exactly emerge as champions of democratic and egalitarian values and were not really revolutionary figures. Instead they appeared to support a strong and legitimate authority, often in the name of a noble personal background fueling his courage, chivalry, and leadership. They may have been outlaws and rebels, but they were often aristocrats by heritage (Don Diego in Zorro and Robin of Huntingdon in Robin Hood) or had earned royal attachment (d'Artagnan). In other words, his screen persona held an elitist allure, one that insisted on the nobility of birthright, character, and deeds. At the same time, while operating in distant lands and remote times, his characters turned a certain primitivism of manners into a primary, almost nostalgic, scene of governance. No matter the character or century, the larger-than-life Anglo-Saxon Fairbanks was always a leader to his socially inferior followers, including women. The commoners and citizens who inhabited his films' exotic worlds appeared grateful to submit to his aristocratic and starlike authority and functioned as social décor in narratives in which justice was ultimately served and conflicts were neatly resolved-as in The Mark of Zorro, Robin Hood, and The Black Pirate. 
Fairbanks's characterization had also a Wilsonian dimension that idealized fair governance against usurpers, illegitimate rulers, and just plain cruel tyrants. He was the recognizably American hero "working on behalf of 'the people' to support and restore the people's regimes of Spanish governors in the two Zorro films [1920, 1925], King Richard the Lion-Heart in Robin Hood [1922], and Louis XIII and XIV, respectively, in The Three Musketeers [1921] and The Iron Mask [1929]." With admirable leadership skills, "Fairbanks did similar deeds while deposing a wicked Mongol usurper in The Thief of Bagdad [1924] and a totalitarian South American dictator in The Gaucho [1928]." "118

His characters did not intend to take over the world, only to return it to its rightful leaders. Their toppling of authoritarian and cruel regimes was set in a mythical and easily romanticized past, not in the present. For Siegfried Kracauer, that was a telling sign. "Douglas Fairbanks, the gallant champion of the oppressed," the German critic remarked, "goes to battle in a previous century against a despotic power whose survival is of no consequences to any American today." ${ }_{19}$

Rather than subvert unfriendly contemporary forms of governance, these nostalgic pageantries articulated a different kind of liberation. Fairbank's celebrity on-screen and off appeared to address a widely felt need for the revitalization of American masculinity. By virtue of his characters' superior moral vigor and athletic skills, his costume adventures sought to restore and perpetuate the wholesome virtues of the ideal American male. It is not surprising, then, that in film after film Fairbanks's characters remained juvenile figures, both diegetically and iconically, and were shielded from emotional and narrative involvement with the new feminine types. In this regard, Fairbanks's 1920 s swashbucklers also paid peculiar homage to boys' literary favorites of the time, from Dumas's The Three Musketeers to Robin Hood and the Arabian Nights, or featured a son eager to please a father figure (i.e., The Mark of Zorro, Don Q, Son of Zorro, and The Black Pirate). In contrast to his films from the teens, his character- and leadership-building narratives showcased protagonists who walk a fine line between comedic playfulness and a marked desire for justice and paternal approval. ${ }^{120}$ In The Mark of Zorro, Don Diego Vega is both the effeminate young man, or mollycoddle, and the fearless and righteous hero who confronts and defeats the local despot and realizes his father's most unlikely expectations. As such, Fairbanks's 1920s films indulged in a patriarchal past that, set in faraway places, oppose a virile, active masculinity against a passive femininity. "The star's retreat into a fictional past," as Studlar has acutely noted, "secured a place where his protagonists could continue their heroics without confronting those adult prerogatives and impurities made synonymous with the Roaring Twenties." ${ }^{121}$ His characters' exuberant male energy was thus safely reinscribed in reassuring narratives of male heroism and unambiguous sexual roles. Neither flappers, competent and erotically powerful women, nor deviant effeminate males were anywhere to be seen in his films. His all-too-insulated film roles deflected any tension between his characters' diegetic youth and his biographical 
age. ${ }^{122}$ Instead, they joyfully took children and nostalgic adult spectators into a world "when life was life, and men were men," as one of the intertitles of The Three Musketeers reads.

When Douglas Fairbanks and Mary Pickford were married in 1920, their love story had the whiff of a scandal, since both had divorced to be together, but also the enduring quality of a fairy tale. They were America's royals after all. ${ }^{123}$ At the height of their fame, they were known as humble royalty, old-fashioned trendsetters, and politically conservative. Their magnificent and exclusive residence of Pickfair, the "Buckingham Palace of Hollywood," was the site of official industry functions and entertainments, regularly covered by the press as a matter of course. ${ }^{124}$ Pickfair "became the nation's second White House and the crossroads of the world for boldface names," from Albert Einstein and Amelia Earhart to King Alfonso VIII of Spain and Babe Ruth, to name a few. The two royals "were, in all but name, unelected officials of the U.S. government, and they shirked none of it." ${ }^{125}$ As iconic embodiments of health, sobriety, and good humor, they also became national and industry spokespeople, especially outside the United States. During their trips abroad, they were regarded, as Pickford herself acknowledged, as "ambassadors, not only of the motion picture industry, but of our own country." 126 For a while, at least.

As the 1920 sent on, the heroes of the Liberty Bond campaigns found themselves restricted to typecast roles that, though still popular at the box office, were increasingly seen as passé. The nation that had catapulted them to world fame and turned them into models of physical activity and innocent youth was grateful to the couple but was also intrigued by not-so-all-American ambassadors and public opinion leaders. The two stars' meeting with Mussolini in Rome in 1926 seems to exemplify this delayed passing of the baton to a different kind of celebritysurprisingly, a foreign one.

In theory, several phenomena should have countered Valentino and Mussolini's degree of nationwide popularity in the political and cinematic affairs of 1920 s America. The Great War's aftermath led to the rise of isolationist and nativist sentiments. Politicians and intellectuals urged the end of what they deemed to be messy political entanglements in international affairs, and their articulation of hyperbolic nativist positions and eugenic hierarchies led Congress to pass unprecedented immigration restrictions ${ }^{127}$ How then could two racially othered foreigners become leading figures in America? Further, how to explain their popularity vis-à-vis the nationalizing trajectory of wartime film stardom that had anointed Pickford and Fairbanks as the most popular icons of an all-American national spirit? And finally, how could two icons of chauvinist Latin masculinity become public opinion leaders in a nation that was undergoing a major democratic expansion in terms of gender equality, social mobility, and political representation? In part 2, I address these questions with respect to Valentino's career trajectory and reveal the critical role of mediators-namely, unofficial publicity agents and various 
kinds of promoters-in the development and consolidation of his popularity. In part 3, I focus on Mussolini's heavily mediated popularity in America during the same period. Both sections focus on two interrelated postwar dynamics pertaining to the internationalization of American film narratives and characters and the rising transnational appeal of foreign, racialized masculinities. 